\title{
Interactions of European Red Mite and Crop Load on Maturity and Quality, Mineral Concentrations, and Economic Value of 'Starkrimson Delicious' Apples
}

\author{
A.H.D. Francesconi \\ Department of Horticultural Sciences, New York State Agricultural Experiment Station, Cornell University, \\ Geneva, NY 14456
}

C.B. Watkins

Department of Fruit and Vegetable Science, Cornell University, Ithaca, NY 14850

A.N. Lakso ${ }^{1,2}$, J.P. Nyrop ${ }^{3}$, J. Barnard ${ }^{4}$, and S.S. Denning ${ }^{2}$
New York State Agricultural Experiment Station, Cornell University, Geneva, NY 14456

Additional index words. Malus domestica, Panonychus ulmi, whole-canopy $\mathrm{CO}_{2}$ exchange, fruit growth, carbon balance, ethylene, watercore, internal breakdown, integrated pest management

\begin{abstract}
Fruit maturity, quality, calcium concentration and economic value of 'Starkrimson Delicious' (Malus domestica Borkh.) apples, under a range of crop levels and European red mite [Panonychus ulmi (Koch)] cumulative mite-days (CMD), were best explained by local surface regression models involving CMD and crop load. Fruit from trees with low CMD and a light crop (125 fruit/tree, about 20 t/ha) were the most mature at harvest. Those fruit had higher ethylene concentrations, starch pattern indices, soluble solids concentrations, and watercore incidence at harvest than fruit from trees with low CMD and a normal crop (300 fruit/tree, about $40 \mathrm{t} / \mathrm{ha}$ ), or with high CMD at any crop level. Those fruit also had higher incidences of watercore and internal breakdown after 4 months of cold storage. Calcium concentrations in fruit increased as crop load and $\mathrm{CMD}$ increased. Whole-canopy net $\mathrm{CO}_{2}$ exchange rate per fruit related better to fruit quality and calcium concentrations than either crop load or CMD alone, but was always a much worse predictor than local surface regressions. Low CMD and normally cropped trees had the highest crop value; lightly cropped trees had an intermediate crop value; while high CMD and normally cropped trees had the lowest crop economic value. Crop load should be considered when defining action thresholds for mites, and harvest schedules for apples should reflect crop load and mite populations on apple trees.
\end{abstract}

European red mite (ERM) (Panonychus ulmi) is an important foliar feeding pest in apple orchards, reducing leaf and wholecanopy net $\mathrm{CO}_{2}$ exchange rate (NCER) (Francesconi et al., 1996; Lakso et al., 1996; Mobley and Marini, 1990). However, the effects of ERM infestations on yield, fruit size and quality, and return bloom of apple trees have been inconsistent in past studies where fruit color, flesh firmness, soluble solids concentration and starch were affected by ERM in some cases but not in others (Ames et al., 1984; Beers et al., 1990; Chapman et al., 1952; Hull and Beers, 1990; Lakso et al., 1996; Marini et al., 1994; Zwick et al., 1976). Such highly variable effects of mites on apple trees are probably due to interactions among pest, environment and physiological status of the trees (Francesconi et al., 1996; Lakso et al., 1996; Marini et al., 1994). One important factor that may influence ERM effects on tree and fruit physiology is crop load. Lightly cropped trees show less severe detrimental effects of mites on fruit quality compared to heavily cropped trees (Ames et al., 1984; Marini et al., 1994;Zwick et al., 1976). Fruit maturity, fruit mineral

\footnotetext{
Received for publication 30 Nov. 1995. Accepted for publication 11 Apr. 1996. This research was funded in part by CAPES, Brazil (Graduate Fellowship for A.H.D.F.), Cornell IPM Program, Geneva, N.Y., and Arthur Boller Apple Research Grant. We gratefully acknowledge Ian Merwin and Warren Stiles for editorial suggestions. Use of trade names does not imply endorsement of the products named nor criticism of similar ones not named. The cost of publishing this paper was defrayed in part by the payment of page charges. Under postal regulations, this paper therefore must be hereby marked advertisement solely to indicate this fact. ${ }^{1}$ To whom reprint requests should be addressed.

${ }^{2}$ Dept. of Horticultural Sciences.

${ }^{3}$ Dept. of Entomology.

${ }^{4}$ Computer center.
}

content and crop load are interrelated and influence fruit quality and the incidence of apple disorders (Ferguson and Watkins, 1992; Marmo et al., 1985; Sharples, 1964, 1968; Volz et al., 1993). Fruit from lightly cropped apple trees tend to be more susceptible to disorders such as bitter pit and watercore than fruit from medium and heavily cropped trees (Ferguson and Watkins, 1989; Marlow and Loescher, 1984).

Carbohydrate supply/demand appears to be the main mechanism for the interactive effects of ERM and crop load on fruit size of 'Starkrimson Delicious' apple trees (Francesconi et al., 1996). Trees with a commercial crop load showed reductions in fruit size earlier and more severely than trees with about half as much crop. Whole-canopy NCER per fruit, an expression of carbohydrate availability to the fruit (Lakso et al., 1996), related to the variation in final fruit size better than cumulative mite-days (CMD) alone, in different years and with various mite levels and crop loads (Francesconi et al., 1996). A negative exponential model fit between fruit size and whole-canopy NCER per fruit was, in practice, similar to the threshold type of response used in integrated pest management. Trees with whole-canopy NCER per fruit between 1.5 and $0.6 \mu \mathrm{mol} \cdot \mathrm{s}^{-1}$ produced the largest apples. Below $0.6 \mu \mathrm{mol} \cdot \mathrm{s}^{-1}$, any further decrease in whole-canopy NCER per fruit resulted in greater reductions in final fruit size. Depending on the degree of reduction of carbohydrate availability to the fruit, mite stress could therefore affect apple maturity and quality.

Mite and crop load interactions can affect fruit size distribution and crop value (Marini et al., 1994) as well as final fruit size and quality (Ames et al., 1984; Francesconi et al., 1996; Lakso et al., 1996; Marini et al., 1994). Thus, looking at all aspects of mite damage is important for a complete evaluation of mite impact on 
apple trees and for the development of risk assessment estimates for mite infestations.

The objective of this study was to evaluate the interactions of ERM and crop load on maturity, quality and mineral concentration, and on fruit size distribution and crop economic value of apples. The relationships between whole-canopy NCER per fruit and maturity and storage potential of apples were also evaluated, as an innovative method to better explain variations in those types of responses of apple trees to mites.

\section{Materials and Methods}

A factorial experiment was established at Geneva, N.Y., in 1994, on eighteen 12-year-old 'Starkrimson Delicious'/M.26 central leader apple trees. There were two target crop levels: light (125 fruit/tree) or normal (300 fruit/tree); and three target mite levels expressed as final cumulative mite-days (CMD) per leaf, monitored weekly from 2 June until harvest: low (<100 CMD), medium (400 to $1000 \mathrm{CMD})$, or high (>1000 CMD). Each tree was an experimental unit and there were three replications per treatment in a completely randomized design. The target levels provided a range of crop load and mite levels appropriate for regression analyses of crop load and mite effects on fruit maturity, incidence of disorders, mineral concentration and crop value. Final crop loads ranged from 119 to 310 fruit/tree or 1.7 to 5.9 fruit $/ \mathrm{cm}^{2}$ trunk cross-sectional area (TCSA); final CMD ranged from 69 to 2394, which were reached at early to mid-August. Experimental details of crop load, mite populations, and whole-canopy NCER per fruit were described in the companion report by Francesconi et al. (1996).

Fruit maturity, minerals, and storage quality. For maturity assessment at harvest (140 d after bloom, 3 Oct.), 10 fruit were harvested on the basis of fruit diameter from each tree around the outer canopy at 1 to $2 \mathrm{~m}$ height. Fruit were sampled in sizes of 70 to $72 \mathrm{~mm}$ for normally cropped trees and 75 to $77 \mathrm{~mm}$ for lightly cropped trees, based on estimations of average fruit size for the two crop load treatments. This sampling method was chosen to minimize effects of fruit size on the evaluated variables within each crop load, so as to examine direct effects of the mites. Internal ethylene concentration (IEC) of each fruit was measured on a 1-mL sample of internal gas withdrawn by a syringe through a hypodermic needle inserted into the core cavity, using gas chromatography (model 3700; Varian Analytical Instruments). Flesh firmness was measured on opposite sides of pared fruit using an EPT-1 pressure tester (Lake City Products, Canada) fitted with an $11.1 \mathrm{~mm}$ head. Soluble solids concentration (SSC) of each apple was measured with a hand refractometer (Atago, Japan) using juice extracted during firmness measurements. Fruit were then cut equatorially and assessed for presence or absence of watercore. The starch index was determined by dipping half of each fruit in potassium-iodine solution and rating hydrolysis of starch on a scale from 1 (100\% starch) to 9 (0\% starch) following Blanpied and Silsby (1992).

The remaining fruit on the trees were harvested on the same day for total count, weight and size determinations and to provide storage samples. Fruit were stored in a cold room at $0^{\circ} \mathrm{C}$ and $79 \%$ relative humidity, for 4 months, and then transferred to a $20^{\circ} \mathrm{C}$ evaluation room. One day after removal from storage, flesh firmness and SSC were measured on 10 fruit samples using the same sampling and analyses methods as before. The same 10 fruit were analyzed for mineral concentrations after storage by taking two cortical plugs from each fruit (Turner et al., 1977). After drying, the plugs were wet-ashed and concentrations of $\mathrm{Ca}, \mathrm{Mg}$, and $\mathrm{K}$ were determined using an inductively coupled argon plasma atomic emission spectrometer at the Analytical Laboratory of the Department of Fruit and Vegetable Science, Cornell University, Ithaca, N.Y. The remaining fruit were assessed for presence or absence of external and internal disorders after one week at $20^{\circ} \mathrm{C}$. This assessment was done on 70 fruit/sample, except for two lightly cropped trees which were limited to 40 and 60 fruit. Fruit without any disorders were classified as sound fruit.

Packout and crop economic value. Apples were counted at harvest, and individual fruit weights and diameters were deter-

Table 1. Fruit per square centimeter trunk cross-sectional area(TCSA), European red mite cumulative mite-days (CMD) and harvest fruit size, maturity, and quality of each experimental 'Starkrimson Delicious' apple tree.

\begin{tabular}{|c|c|c|c|c|c|c|c|c|c|}
\hline $\begin{array}{l}\text { Trees } \\
\text { ranked } \\
\text { by } \\
\text { crop } \\
\text { load }\end{array}$ & $\begin{array}{l}\text { Fruit/ } \\
\text { TCSA }\end{array}$ & CMD & $\begin{array}{c}\text { Canopy } \\
\text { net } \mathrm{CO}_{2} \\
\text { exchange } \\
\text { per fruit } \\
\left(\mu \mathrm{mol} \cdot \mathrm{s}^{-1}\right)\end{array}$ & $\begin{array}{c}\text { Mean } \\
\text { fruit } \\
\text { wt } \\
\text { per tree } \\
\quad(\mathrm{g})\end{array}$ & $\begin{array}{l}\text { Internal } \\
\text { ethylene } \\
\text { concn } \\
\left(\mu \mathrm{L} \cdot \mathrm{L}^{-1}\right)\end{array}$ & $\begin{array}{l}\text { Firmness } \\
(\mathrm{N})\end{array}$ & $\begin{array}{c}\text { Soluble } \\
\text { solids } \\
\text { concn } \\
(\%)\end{array}$ & $\begin{array}{l}\text { Starch } \\
\text { pattern } \\
\text { index } \\
(1-9)\end{array}$ & $\begin{array}{c}\text { Water } \\
\text { core } \\
(\%)\end{array}$ \\
\hline 1 & 1.7 & 781 & 1.42 & 177 & 13.7 & 72.7 & 11.1 & 2.8 & 60 \\
\hline 2 & 2.0 & 578 & 1.38 & 206 & 59.3 & 74.4 & 11.8 & 3.3 & 70 \\
\hline 3 & 2.5 & 1093 & 0.77 & 179 & 0.4 & 75.5 & 10.8 & 2.0 & 20 \\
\hline 4 & 2.6 & 2168 & 0.46 & 177 & 0.2 & 72.7 & 10.2 & 2.4 & 0 \\
\hline 5 & 2.7 & 787 & 0.74 & 191 & 37.2 & 73.3 & 11.4 & 3.2 & 60 \\
\hline 6 & 2.7 & 906 & 0.94 & 204 & 54.7 & 73.8 & 12.1 & 3.7 & 90 \\
\hline 7 & 2.9 & 452 & 0.94 & 197 & 45.3 & 74.0 & 11.7 & 3.2 & 90 \\
\hline 8 & 3.0 & 69 & 0.86 & 189 & 67.7 & 76.3 & 14.3 & 3.3 & 80 \\
\hline 9 & 3.1 & 1764 & 0.57 & 180 & 11.9 & 74.5 & 11.7 & 2.9 & 40 \\
\hline 10 & 4.1 & 1756 & 0.49 & 159 & 5.1 & 75.2 & 11.1 & 2.2 & 50 \\
\hline 11 & 4.4 & 115 & 0.54 & 171 & 2.3 & 73.6 & 11.1 & 2.4 & 0 \\
\hline 12 & 4.4 & 136 & 0.63 & 197 & 18.6 & 74.5 & 11.3 & 2.9 & 50 \\
\hline 13 & 4.4 & 2394 & 0.39 & 141 & 0.1 & 76.6 & 9.8 & 2.1 & 10 \\
\hline 14 & 4.5 & 807 & 0.39 & 161 & 4.0 & 73.9 & 10.0 & 2.7 & 20 \\
\hline 15 & 4.7 & 1982 & 0.31 & 140 & 3.4 & 72.3 & 10.2 & 2.5 & 30 \\
\hline 16 & 4.9 & 993 & 0.51 & 155 & 0.1 & 74.0 & 10.1 & 2.1 & 0 \\
\hline 17 & 5.2 & 554 & 0.48 & 177 & 9.0 & 75.5 & 11.2 & 2.2 & 20 \\
\hline 18 & 5.9 & 878 & 0.35 & 134 & 0.1 & 75.8 & 10.9 & 1.9 & 0 \\
\hline
\end{tabular}


Table 2. Fruit maturity, quality, and minerals after storage for each experimental 'Starkrimson Delicious' apple tree.

\begin{tabular}{|c|c|c|c|c|c|c|c|c|c|}
\hline \multirow[t]{2}{*}{$\begin{array}{l}\text { Trees } \\
\text { ranked } \\
\text { by } \\
\text { crop } \\
\text { load }\end{array}$} & \multirow{2}{*}{$\begin{array}{l}\text { Firmness } \\
(\mathrm{N})\end{array}$} & \multirow{2}{*}{$\begin{array}{c}\text { Soluble } \\
\text { solids } \\
\text { concn } \\
(\%)\end{array}$} & \multirow{2}{*}{$\begin{array}{l}\text { Water } \\
\text { core } \\
(\%)\end{array}$} & \multirow{2}{*}{$\begin{array}{c}\text { Internal } \\
\text { breakdown } \\
(\%)\end{array}$} & \multirow{2}{*}{$\begin{array}{c}\text { Superficial } \\
\text { scald } \\
(\%)\end{array}$} & \multirow{2}{*}{$\begin{array}{l}\text { Sound } \\
\text { fruit } \\
(\%)\end{array}$} & \multicolumn{3}{|c|}{$\begin{array}{l}\text { Fruit mineral concn } \\
\qquad\left(\mu \mathrm{g} \cdot \mathrm{g}^{-1} \text { dry wt }\right)\end{array}$} \\
\hline & & & & & & & $\mathrm{Ca}$ & $\mathrm{K}$ & $\mathrm{Mg}$ \\
\hline$\overline{1}$ & 64.9 & 13.0 & 13 & 35 & 5 & 60 & 126 & 7453 & 258 \\
\hline 2 & 69.6 & 13.4 & 25 & 47 & 5 & 41 & 136 & 6926 & 216 \\
\hline 3 & 66.7 & 13.3 & 3 & 6 & 2 & 91 & 139 & 7097 & 214 \\
\hline 4 & 65.4 & 11.9 & 2 & 2 & 3 & 94 & 152 & 5924 & 250 \\
\hline 5 & 66.5 & 13.2 & 7 & 29 & 4 & 67 & 158 & 4808 & 247 \\
\hline 6 & 66.5 & 13.3 & 17 & 33 & 4 & 56 & 141 & 6823 & 255 \\
\hline 7 & 64.2 & 13.5 & 9 & 19 & 10 & 63 & 132 & 8516 & 215 \\
\hline 8 & 69.0 & 16.1 & 40 & 41 & 3 & 57 & 137 & 6705 & 251 \\
\hline 9 & 64.4 & 13.6 & 3 & 7 & 3 & 87 & 146 & 4586 & 234 \\
\hline 10 & 68.0 & 12.6 & 2 & 4 & 0 & 94 & 163 & 7527 & 247 \\
\hline 11 & 64.5 & 13.5 & 4 & 4 & 19 & 74 & 147 & 3246 & 211 \\
\hline 12 & 68.3 & 13.5 & 10 & 20 & 6 & 70 & 138 & 5462 & 229 \\
\hline 13 & 65.5 & 11.7 & 0 & 0 & 7 & 93 & 173 & 5002 & 229 \\
\hline 14 & 63.2 & 11.8 & 1 & 11 & 0 & 87 & 140 & 5997 & 244 \\
\hline 15 & 64.8 & 11.8 & 0 & 1 & 0 & 99 & 167 & 5400 & 251 \\
\hline 16 & 67.4 & 12.3 & 5 & 10 & 5 & 85 & 155 & 5567 & 229 \\
\hline 17 & 67.9 & 13.6 & 6 & 9 & 6 & 84 & 146 & 4683 & 228 \\
\hline 18 & 66.6 & 13.8 & 0 & 1 & 9 & 90 & 157 & 7842 & 234 \\
\hline
\end{tabular}

mined for all fruit. The distribution of fruit diameters and weights was assessed for each tree. Fruit color was not clearly affected by the treatments, so economic analyses were made on the basis of fruit size alone. Crop value per tree was estimated by using fruit distribution data for each tree and typical prices for various 'Red Delicious' apple size categories provided by a commercial packout (Lake Ontario Fruit, Inc., Albion, N.Y.) in Jan. 1995. Values for the different fruit sizes were as follows: juice $(<57.2 \mathrm{~mm})=\$ 0.08 /$ $\mathrm{kg}$; twelve $1.4 \mathrm{~kg}$ bags $(57.2$ to $69.8 \mathrm{~mm})=\$ 9.00 ; 125$ count trays (69.9 to $71.4 \mathrm{~mm}$ ), 113 count trays ( 71.5 to $74.6 \mathrm{~mm}$ ), and 100 count trays $(74.7$ to $76.2 \mathrm{~mm})=\$ 11.00 /$ box; 88 count trays $(76.3$ to $80.9 \mathrm{~mm}), 80$ count trays ( 81.0 to $84.1 \mathrm{~mm})$, and 72 count trays $(84.2$ to $85.7 \mathrm{~mm})=\$ 12.00 /$ box ; and 64 count trays $(85.8 \mathrm{~mm}$ and above $)=\$ 11.00 /$ box

Statistical analyses. Because individual crop loads and ERM populations were measured and not simply categorized, the data for each tree were presented and analyzed with regression techniques. Our general statistical approach was to look at a variety of regression models and identify which models best fitted the observations. Models were evaluated using both magnitude of $R^{2}$ and qualitative conformance to the data. Each response variable was regressed against the following models: simple linear regressions with CMD, crop load or whole-canopy NCER per fruit; multiple linear regression models with CMD and crop load, with or without an interaction term; and locally weighted regression with CMD and crop load. JMP(SAS Institute., Cary, N.C.) was used for standard regression analysis, and SPLUS (StatSci, Seattle, Wash.) for fitting and plotting local regression surfaces (Cleveland and Devlin, 1988).

\section{Results}

Data sets for crop load and mite treatments were complex, and a large number of variates were evaluated (Tables 1-3), making graphical presentation difficult. Local regression surface models including CMD and crop load best fit all evaluated response variables, and illustrate the nonlinear nature of the data (Figs. 1-
4). It should be noted that an apparent interaction of CMD and crop load greatly reduced fruit weight from trees with high CMD and a normal crop (i.e., >1000 CMD and 5 to 6 fruit/TCSA) in this trial (Francesconi et al., 1996).

Fruit maturity and quality factors at harvest. Fruit from trees with low CMD and a light crop had the highest IEC, SSC, starch pattern indices, and watercore incidence, indicating an interaction between CMD and crop load effects (Fig. 1 A-D). Fruit from trees with high CMD and a light crop and from trees with a normal crop under all CMD had the lowest levels of IEC, SSC, starch pattern indices, and watercore. Flesh firmness was not influenced by crop load or CMD (regressions not shown).

Watercore incidence was positively associated with IEC $\left(r^{2}=\right.$ 0.85 , watercore at harvest $=8.8+2.9 \times$ IEC $-0.03 \times$ IEC), starch pattern indices $\left(r^{2}=0.76\right.$, watercore at harvest $=-97.0+51.3 \times$ starch $)$, and SSC $\left(r^{2}=0.51\right.$, watercore at harvest $=-207.1+22.1$ $\times$ SSC).

Fruit quality after storage. Soluble solids concentration after storage was higher on fruit from trees with low CMD and a light crop (Fig. 2A). Flesh firmness was unaffected by crop load or CMD (regressions not shown). Watercore and internal breakdown incidence indicated an interaction between crop load and CMD, with the highest incidence of disorders occurring in fruit from trees with low CMD and a light crop (Fig. 2 B and C). Consequently, there were fewer sound fruit from trees with low CMD and a light crop (Fig. 2D). Superficial storage scald was not affected by mites or crop load (regressions not shown).

Fruit mineral concentration. Fruit calcium concentration increased as crop load and CMD increased (Fig. 3). Calcium concentration was negatively associated with SSC, starch pattern index, IEC, and watercore at harvest, and SSC, watercore and internal breakdown after storage; however all $y^{2}$ for simple linear regressions were only 0.40 or less. Calcium concentration was positively associated with percentage of sound fruit but the $r^{2}$ for linear regression was only 0.45 .

Even though crop load was positively associated with calcium 
Table 3. Number of fruit in each fruit diameter category, total number of fruit per tree and crop economic value (\$/tree) of each experimental 'Starkrimson Delicious' apple tree.

\begin{tabular}{|c|c|c|c|c|c|c|c|c|c|c|c|}
\hline \multirow{2}{*}{$\begin{array}{l}\text { Trees } \\
\text { ranked } \\
\text { by } \\
\text { crop } \\
\text { load }\end{array}$} & \multicolumn{9}{|c|}{ Fruit diam categories (mm) } & \multirow{2}{*}{$\begin{array}{l}\text { Total } \\
\text { fruit } \\
\text { per } \\
\text { tree } \\
\text { (no.) }\end{array}$} & \multirow{2}{*}{$\begin{array}{c}\text { Crop } \\
\text { value } \\
\text { per } \\
\text { tree } \\
(\$)\end{array}$} \\
\hline & $<57.2$ & $\begin{array}{c}57.2- \\
69.8\end{array}$ & $\begin{array}{c}69.9- \\
71.4\end{array}$ & $\begin{array}{c}71.5- \\
74.6\end{array}$ & $\begin{array}{c}74.7- \\
76.2\end{array}$ & $\begin{array}{c}76.3- \\
80.9\end{array}$ & $\begin{array}{c}81.0- \\
84.1\end{array}$ & $\begin{array}{c}84.2- \\
85.7\end{array}$ & $\geq 85.8$ & & \\
\hline 1 & 0 & 22 & 7 & 46 & 7 & 26 & 7 & 0 & 2 & 119 & 11.67 \\
\hline 2 & 0 & 9 & 8 & 38 & 13 & 57 & 24 & 7 & 7 & 162 & 19.58 \\
\hline 3 & 0 & 26 & 15 & 41 & 26 & 39 & 10 & 4 & 3 & 163 & 16.77 \\
\hline 4 & 1 & 27 & 17 & 41 & 29 & 40 & 12 & 0 & 1 & 169 & 16.95 \\
\hline 5 & 1 & 14 & 9 & 41 & 33 & 64 & 21 & 3 & 0 & 185 & 20.98 \\
\hline 6 & 0 & 13 & 4 & 19 & 13 & 79 & 33 & 3 & 4 & 170 & 21.07 \\
\hline 7 & 1 & 14 & 10 & 32 & 38 & 79 & 22 & 3 & 1 & 200 & 23.30 \\
\hline 8 & 0 & 21 & 6 & 54 & 21 & 44 & 6 & 0 & 0 & 153 & 15.73 \\
\hline 9 & 0 & 14 & 12 & 37 & 26 & 48 & 8 & 0 & 1 & 146 & 15.80 \\
\hline 10 & 4 & 71 & 34 & 89 & 32 & 26 & 1 & 0 & 0 & 257 & 20.89 \\
\hline 11 & 0 & 56 & 30 & 96 & 40 & 53 & 0 & 0 & 0 & 274 & 25.05 \\
\hline 12 & 0 & 17 & 13 & 44 & 35 & 119 & 28 & 5 & 1 & 263 & 31.19 \\
\hline 13 & 1 & 125 & 31 & 32 & 5 & 4 & 0 & 0 & 0 & 198 & 10.06 \\
\hline 14 & 0 & 96 & 50 & 70 & 33 & 40 & 2 & 0 & 0 & 293 & 23.42 \\
\hline 15 & 6 & 167 & 45 & 60 & 18 & 14 & 0 & 0 & 0 & 310 & 17.92 \\
\hline 16 & 4 & 108 & 52 & 69 & 27 & 22 & 1 & 0 & 0 & 283 & 20.38 \\
\hline 17 & 3 & 39 & 27 & 71 & 51 & 108 & 3 & 1 & 0 & 301 & 31.14 \\
\hline 18 & 3 & 195 & 40 & 38 & 16 & 7 & 0 & 0 & 0 & 300 & 15.04 \\
\hline
\end{tabular}

concentration ( $\mu \mathrm{g} \mathrm{Ca} / \mathrm{g}$ fruit dry weight), it was negatively associated with total grams of calcium per fruit (data not shown). CMD had no effect on total calcium per fruit (data not shown). Because most calcium uptake in the fruit occurs early in the season (Faust, 1989; Rogers and Batjer, 1954), middle- to late-season mite populations were not expected to markedly affect the absolute amount of calcium per fruit. Because fruit were larger on trees with low CMD and a light crop, more dilution of calcium probably occurred in those fruit by harvest.

Whole-canopy net $\mathrm{CO}_{2}$ exchange rate per fruit effects on fruit maturity, quality, and mineral concentration. There was a positive relationship between middleto late-season whole-canopy NCER per fruit, measured after mites were killed, and IEC, SSC, starch indices and watercore at harvest, and SSC and watercore after storage; however, $r^{2}$ for simple linear regressions were all less than 0.50. Whole-canopy NCER per fruit was negatively related to fruit calcium concentration, but $r^{2}$ for linear regression was only 0.53 . As whole-canopy NCER per fruit increased, there was an increase in the percentage of fruit with internal breakdown $\left(r^{2}=0.73\right.$, internal breakdown $=-11.3+39.7 \times$ canopy NCER/ fruit), and a decrease in the percentage of sound fruit $\left(r^{2}\right.$ $=0.73$, sound fruit $=107.2-43.9 \times$ canopy NCER/ fruit). Whole-canopy NCER per fruit was a better predictor of fruit quality, maturity and mineral concen-

Fig. 1. Local regression surface fit of $(\mathbf{A})$ internal ethylene concentration (IEC) $\left(R^{2}=0.83, P<0.005\right),(\mathrm{B})$ soluble solids concentration $\left(R^{2}=\right.$ $0.90, P<0.001),(\mathbf{C})$ starch pattern index $\left(R^{2}=0.65, P<0.13\right)$, and (D) percentage of fruit with watercore $\left(R^{2}=0.80, P<0.02\right)$ vs. number of fruit $/ \mathrm{cm}^{2}$ trunk cross-sectional area (fruit/TCSA) and European red mite final cumulative mite-days (CMDs) on 'Starkrimson Delicious' apples at harvest. Error df $=10$ for all surfaces. Solid and open circles are data above and below the surface, respectively. tration than either crop load or mite levels, for all variables mentioned above, except for SSC at harvest and after storage (regressions not shown). However, local regression surfaces had much higher $R^{2}$ for all fruit quality, maturity and mineral variates than whole-canopy NCER per fruit (Figs. 1-3).

Crop economic value. Mites caused a greater reduction of crop value in trees with normal crop loads than in trees with light crop loads (Fig. 4). Trees with high CMD and a normal crop load had the lowest crop values, while trees with low CMD and a normal
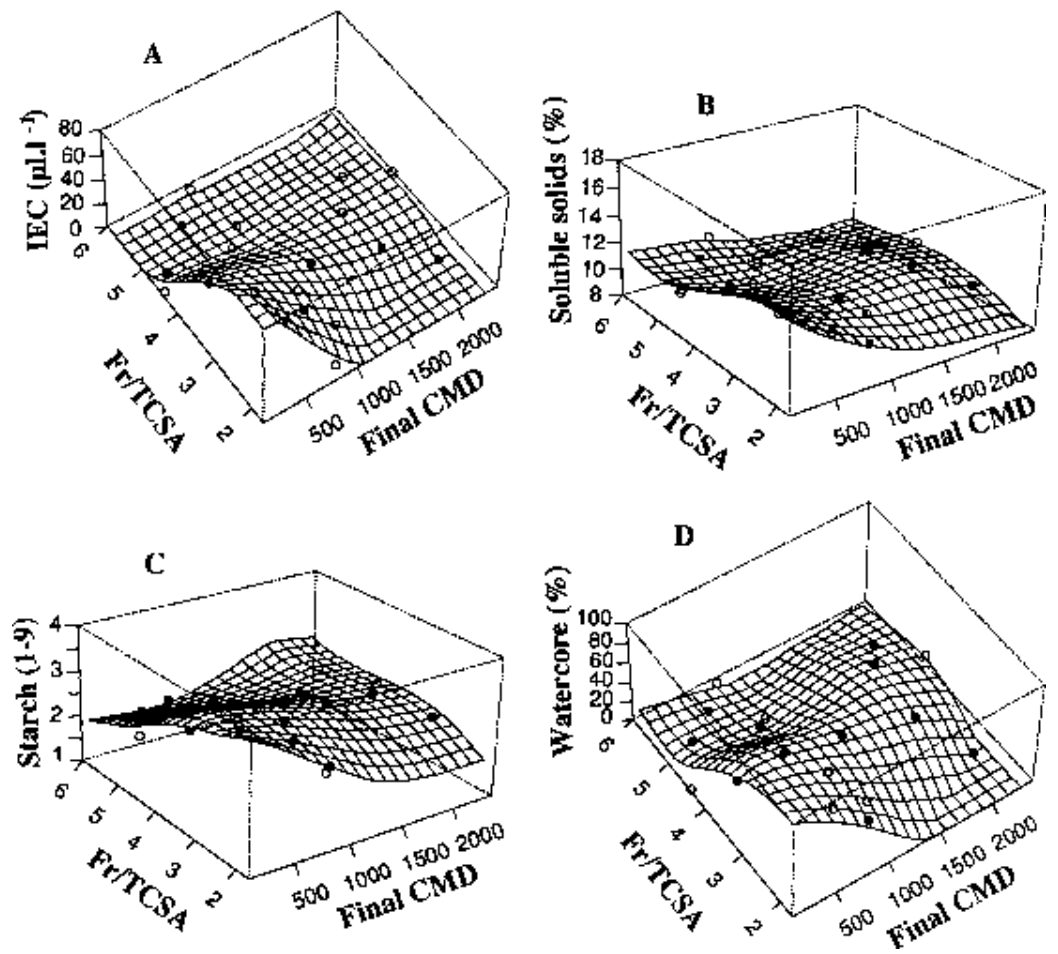

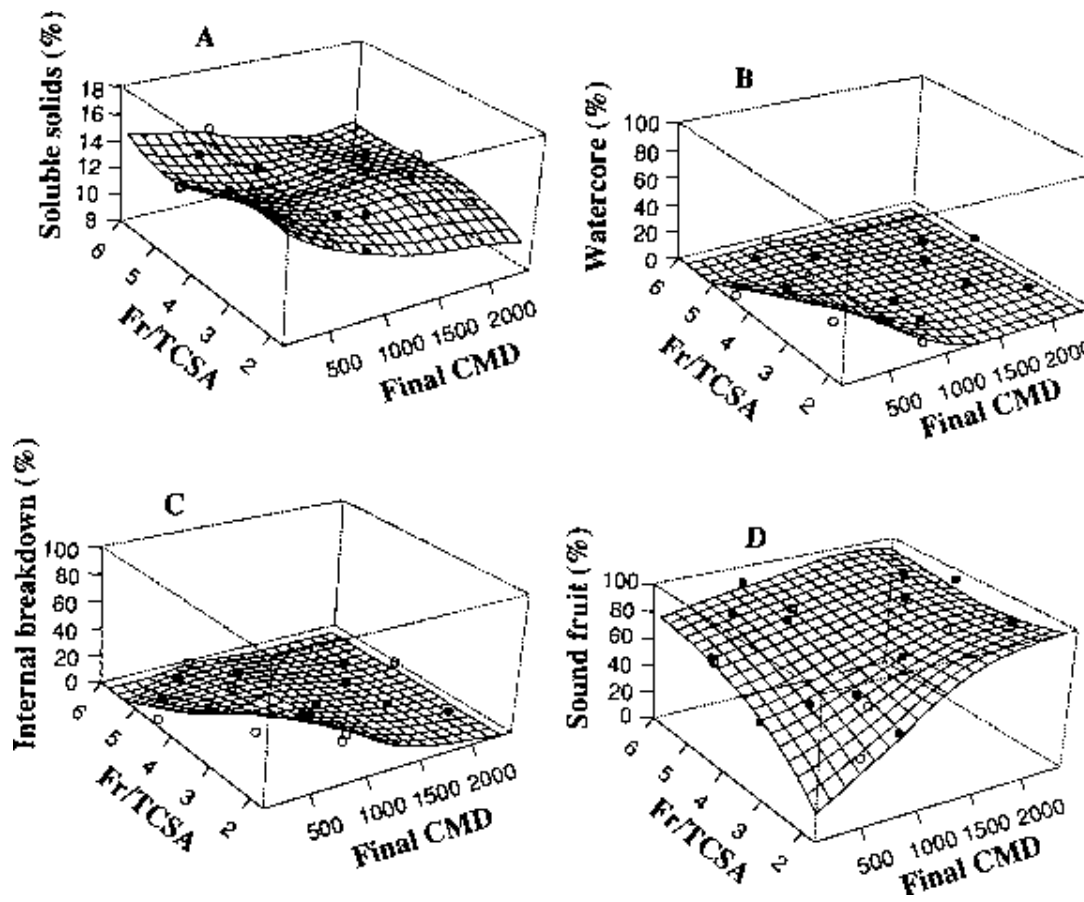

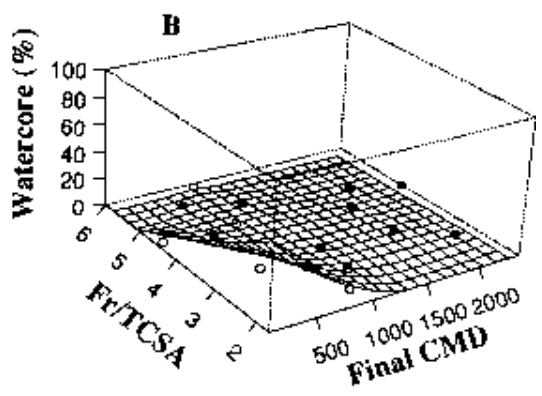

Fig. 2. Local regression surface fit of (A) soluble solids concentration $\left(R^{2}=0.92, P<0.001\right)$, and percentage of fruit with (B) watercore $\left(R^{2}=0.84, P<0.005\right)$, (C) internal breakdown $\left(R^{2}\right.$ $=0.84, P<0.005)$, and $(\mathbf{D})$ sound fruit $\left(R^{2}=0.87, P<0.002\right) \mathrm{vs}$. number of fruit $/ \mathrm{cm}^{2}$ trunk cross-sectional area (fruit/TCSA) and European red mite final cumulative mite-days (CMD) on 'Starkrimson Delicious' apples after storage. Error $\mathrm{df}=10$ for all surfaces. Solid and open circles are data above and below the surface, respectively.

variation than the local regression surface models with CMD and crop load. Thus, whole-canopy NCER per fruit, an estimator of carbohydrate availability to the fruit in middle to late season, is a better predictor of final fruit size (Francesconi et al., 1996) than of fruit quality and maturity at harvest, from trees with various mite and crop levels.

Lower fruit calcium concentration from trees with low CMD and a light crop might also have contributed to more advanced maturity and increased fruit disorders, as previously reported for lightly cropped trees by Ferguson and Watkins (1992). The relationships between carbohydrate and mineral levels in terms of fruit development and maturity are

crop load had the highest crop values. Lightly cropped trees under any CMD had an intermediate crop value. We assumed there was no fruit loss due to disorders at harvest or after storage when calculating the crop economic value. Including incidence of disorders such as watercore and internal breakdown in an economic scenario presents a series of difficulties. For instance, the level of watercore severity that is acceptable varies with market conditions, the incidence and severity of watercore tends to reduce during storage, and the incidence of internal breakdown varies a lot with time of storage.

\section{Discussion}

Fruit from trees with low CMD and a light crop were the most mature at harvest, based on higher IEC, starch pattern indices, SSC and the incidence of watercore. Relatively few studies have been published on effects of crop load on fruit maturation, but light crop load is associated with advanced fruit maturity (Ferguson and Watkins, 1992). We concluded that advanced maturity in lightly cropped trees of our study was not due to the fact that sampled fruit of those trees were larger than sampled fruit from normally cropped trees, because random samples collected from every tree also indicated similarly higher SSC and starch pattern indices on fruit from low $\mathrm{CMD}$ and lightly cropped trees across various fruit sizes.

Interestingly, high CMD reduced the impact of crop load on fruit maturity, suggesting that reduced carbohydrate availability to the fruit retarded fruit maturity and watercore occurrence. Lakso et al. (1996) found no effects of mites on apple quality. Even though Ames et al. (1984) and Marini et al. (1994) reported that mites caused more severe reductions of SSC of apples from heavily cropped trees than from lightly cropped trees, SSC is not a reliable index of fruit maturity (Jackson et al., 1977; Lau, 1985). On the other hand, increased IEC (Knee et al., 1983), and other related changes such as increased watercore at harvest and occurrence of flesh breakdown after storage (Marlow and Loescher, 1984), are more reliable indices of advanced maturity and were found in our study.

Even though apples from trees with higher whole-canopy NCER per fruit tended to be more mature and to have higher incidence of disorders than fruit from trees with lower wholecanopy NCER per fruit, those models explained much less of the

\section{still poorly understood.}

Determination of optimal harvest dates and prediction of storage potential of 'Delicious' apples apparently requires attention to factors such as crop load and pest levels on the trees. 'Starkrimson Delicious' fruit from trees with low CMD and a light crop should be harvested earlier than fruit from trees with higher crop loads under any mite level, or from trees with high CMD and a light crop.

Packout categories and dollar values vary considerably with cultivar, packer, time of the season and year. The cost of pest control also varies with year and pesticide used. However, the general physiological responses are often more predictable and useful in making decisions on pest control strategies. Increases in crop economic value with crop load under low mite population, and greater reductions in crop value due to high mite infestation on heavier crop load trees compared to lighter crop load trees were similar to that recently reported by Marini et al. (1994). Even greater reductions in crop value would be expected if prices had a

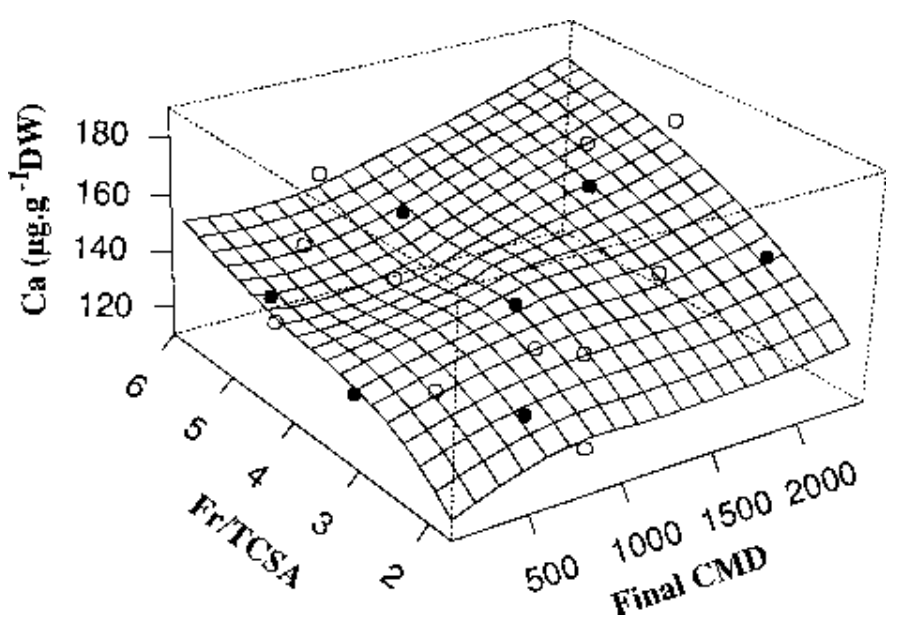

Fig. 3. Local regression surface fit of fruit calcium concentration $\left(\mu \mathrm{g} \cdot \mathrm{g}^{-1}\right.$ fruit dry weight) after storage vs. number of fruit $/ \mathrm{cm}^{2}$ trunk cross-sectional area (fruit/ TCSA) and European red mite final cumulative mite-days (CMD) on 'Starkrimson Delicious' apples after storage $\left(R^{2}=0.83, P<0.004\right.$, Error df $\left.=10\right)$. Solid and open circles are data above and below the surface, respectively. 


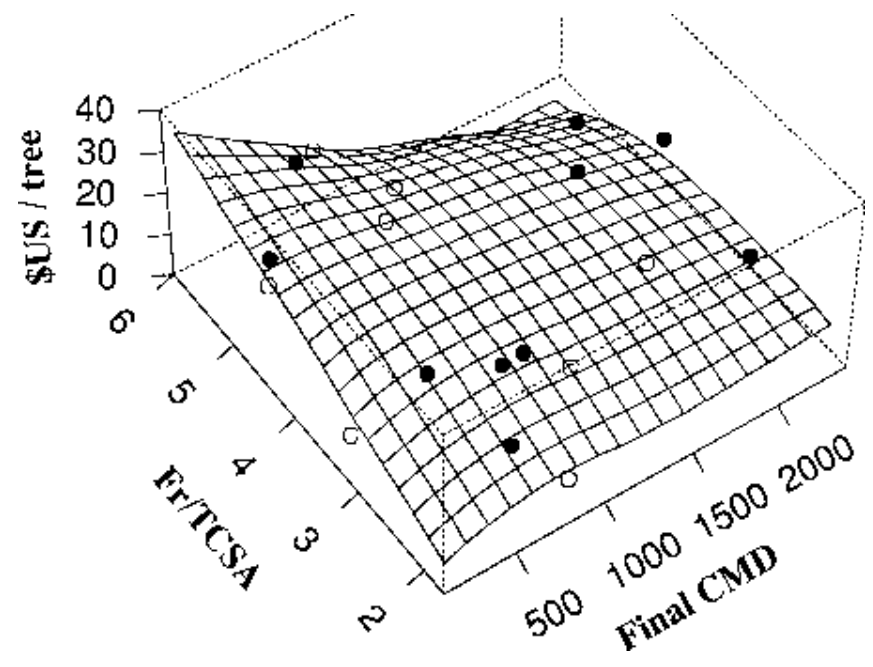

Fig. 4. Local regression surface fitted to our data on crop economic value in terms of dollars received per tree ( $\$ /$ tree) vs. number of fruit $/ \mathrm{cm}^{2}$ trunk cross-sectional area (fruit/TCSA) and European red mite final cumulative mite-days (CMD) on 'Starkrimson Delicious' apple trees $\left(R^{2}=0.81, P<0.01\right.$, Error $\left.\mathrm{df}=10\right)$. Solid and open circles are data above and below the surface, respectively.

more severe variation with size than they did in our economic scenario. Increases in crop load increased the sensitivity of the tree to high mite populations in terms of mean fruit size (Francesconi et al., 1996) and caused reductions in crop value. Our study reinforces the importance of considering both crop load and mite development when defining action thresholds for mites on apples.

\section{Literature Cited}

Ames, G.K., D.T. Johnson, and R.C. Rom. 1984. The effect of European red mite feeding on the fruit quality of 'Miller Sturdeespur' apple. J. Amer. Soc. Hort. Sci. 109:834-837.

Beers, E.H., L.A. Hull, and G.M. Greene. 1990. Effect of a foliar urea application and mite injury on yield and fruit quality of apple. J. Econ. Entomol. 83:552-556.

Blanpied, G.D. and K.J. Silsby. 1992. Predicting harvest date windows for apples. Cornell Coop. Ext. Info. Bul. 221:1-12.

Chapman, P.J., S.E. Lienk, and O.F. Curtis, Jr. 1952. Responses of apple trees to mite infestations: I. J. Econ. Entomol. 45:815-821.

Cleveland, W.S. and S.J. Devlin. 1988. Locally-weighted regression: an approach to regression analysis by local fitting. J. Amer. Stat. Assn. 83:596-610.

Faust, M. 1989. Physiology of temperate zone fruit trees. Wiley, New York.
Ferguson, I.B. and C.B. Watkins. 1989. Bitter pit in apple fruit. Hort. Rev. 11:289-355.

Ferguson, I.B. and C.B. Watkins. 1992. Crop load affects mineral concentrations and incidence of bitter pit in 'Cox's Orange Pippin' apple fruit. J. Amer. Soc. Hort. Sci. 117:373-376.

Francesconi, A.H.D., A.N. Lakso, J.P. Nyrop, J. Barnard, and S.S. Denning. 1996. Carbon balance as a physiological basis for the interactions of European red mite and crop load on 'Starkrimson Delicious' apple trees. J. Amer. Soc. Hort. Sci 121:959-966.

Hull, L.A. and E.H. Beers. 1990. Validation of injury thresholds for European red mite (Acari: Tetranychidae) on 'Yorking' and 'Delicious' apples. J. Econ. Entomol. 83:2026-2031.

Jackson, J.E., J.W. Palmer, M.A. Perring, and R.O. Sharples. 1977. Effects of shade on the growth and cropping of apple trees. III. Effects on fruit growth, chemical composition and quality at harvest and after storage. J. Hort. Sci. 52:267-282.

Knee, M., S.M. Smith, and D.S. Johnson. 1983. Comparison of methods for estimating the onset of the respiration climacteric in unpicked apples. J. Hort. Sci. 58:521-526.

Lakso, A.N., G.B. Mattii, J.P. Nyrop, and S.S. Denning. 1996. Influence of European red mite on leaf and whole-canopy carbon dioxide exchange, yield, fruit size, quality, and return cropping in 'Starkrimson Delicious' apple trees. J. Amer. Soc. Hort. Sci. 121:954-958.

Lau, O.L. 1985. Harvest indices for B.C. apples. British Columbia Orchardist 7:1A-20A

Marini, R.P., D.G. Pfeiffer, and D.S. Sowers. 1994. Influence of European red mite (Acari:Tetranychidae) and crop density on fruit size and quality and on crop value of 'Delicious' apples. J. Econ. Entomol. 87:1302-1311.

Marlow, G.C. and W.H. Loescher. 1984. Watercore. Hort. Rev. 6:189251.

Marmo, C.A., W.J. Bramlage, and S.A. Weis. 1985. Effects of fruit maturity, size, and mineral concentrations on predicting the storage life of 'McIntosh' apples. J. Amer. Hort. Sci. 110:499-502.

Mobley, K.N. and R.P. Marini. 1990. Gas exchange characteristics of apple and peach leaves infested by European red mite and twospotted spider mite. J. Amer. Soc. Hort. Sci. 115:757-761.

Rogers, B.L. and L.P. Batjer. 1954. Seasonal trends of six nutrient elements in the flesh of Winesap and Delicious apple fruits. Proc. Amer. Soc. Hort. Sci 63:67-73.

Sharples, R.O. 1964. The effects of fruit thinning on the development of Cox's Orange Pippin apples in relation to the incidence of storage disorders. J. Hort. Sci. 39:224-235.

Sharples, R.O. 1968. Fruit-thinning effects on the development and storage quality of Cox's Orange Pippin apple fruits. J. Hort. Sci. 43:359-371.

Turner, N.A., I.B. Ferguson, and R.O. Sharples. 1977. Sampling and analysis for determining the relationship of calcium concentration to bitter pit in apple fruit. N.Z. J. Agr. Res. 20:525-532.

Volz, R.K., I.B. Ferguson, J.H. Bowen, and C.B. Watkins. 1993. Crop load effects on fruit mineral nutrition, maturity, fruiting and tree growth of 'Cox's Orange Pippin' apple. J. Hort. Sci. 68:127-137.

Zwick, R.W., G.J. Fields, and W.M. Mellenthin. 1976. Effects of mite population density on 'Newtown' and 'Golden Delicious' apple tree performance. J. Amer. Soc. Hort. Sci. 101:123-125 